\title{
2: 208220192-208289079
}

National Cancer Institute

\section{Source}

National Cancer Institute. 2: 208220192-208289079. NCI Thesaurus. Code C41987.

Physical location of CREB1_Gene 